\title{
The Influence of Different Concentrations of a Natural Clay Material as Active Principle in Cosmetic Formulations
}

\author{
Júlia Daneluz ${ }^{a}$, Juliana da Silva Favero ${ }^{a}$,Venina dos Santos ${ }^{a *}$ (D), Valeria Weiss-Angeli ${ }^{(\mathbb{D})}$, \\ Lucas Bonan Gomes ${ }^{b}$ (D), André Sampaio Mexias ${ }^{b}$, Carlos Pérez Bergmann ${ }^{b}$ \\ ${ }^{a}$ Universidade de Caxias do Sul (UCS), Rua Francisco Getúlio Vargas, 1130, 95070-560, Caxias do Sul, \\ RS, Brasil \\ ${ }^{b}$ Universidade Federal do Rio Grande do Sul (UFRGS), Av. Bento Gonçalves, 9500, 91501-970, \\ Porto Alegre, RS, Brasil
}

Received: October 16, 2019; Revised: February 19, 2020; Accepted: April 25, 2020

\begin{abstract}
The clay minerals have characteristics and properties that allow their applicability in the cosmetic area, being incorporated into formulations as an active principle. Therefore, the aim of this work is characterizing and evaluating the influence of a clay from Miracema do Norte, Tocantins, Brazil, named Clay V, on the physicochemical characteristics of a hydrophilic gel of Aristoflex ${ }^{\circledR}$, a copolymer of the neutralized acryloyldimethyltaurate and vinylpyrrolidone sulphonic acid. Clay V was decontaminated and characterized through microbiological evaluation, crystalline phases present by X-Ray Diffraction (XRD), chemical composition by X-Ray Fluorescence (XRF), thermogravimetric analysis (TGA) and granulometric distribution by sieving. Gels were prepared using Clay $\mathrm{V}$ with particles in the range $\leq 180 \mu \mathrm{m}$ in three different concentrations: $1 \%, 3 \%$ and $5 \%$ (w/w) and a standard gel without clay. The formulations were evaluated according to organoleptic characteristics, $\mathrm{pH}$, viscosity, spreadability and the centrifugation test. The microbiological evaluation showed that the clay sample is in compliance with the parameters established by the legislation. The following mineral phases were identified by XRD: kaolinite, illite, vermiculite and quartz, mainly composed of silica and alumina according to XRF. Thermal analysis showed that the clay has two thermal decomposition reactions, the largest being $547.6^{\circ} \mathrm{C}$. The granulometric analysis identified that the largest fraction (63.22\%) was of particles with sizes greater than $710 \mu \mathrm{m}$. The organoleptic characteristics presented by the formulations were suitable, with characteristic gel odor, homogeneous appearance, soft and refreshing texture and staining based on the concentration of Clay $\mathrm{V}$ used. The obtained $\mathrm{pH}$ values were within the range between 5.5 and 6.5, and it was verified that the gel has high spreadability, distributing evenly on the skin. The values obtained for viscosity showed that the formulations are non-Newtonian fluids with pseudoplastic behavior. The centrifugation test showed that the formulations are stable, with no phase separation. The results obtained with the tests showed that the natural clay $\mathrm{V}$ material is beneficial in cosmetic products and can be used for incorporation in cosmetic gel formulations of Aristoflex ${ }^{\circledR}$ type.
\end{abstract}

Keywords: clay minerals, cosmetics, formulation, gel.

\section{Introduction}

Due to their compositions, unique properties and applications, clays are attractive materials in several areas, including cosmetology ${ }^{1}$. In the segment of cosmetology, clays, according to their chemical and mineralogical composition, are used because of their moisturizing, skin oiliness reducing, anti-aging and makeup properties $\mathrm{s}^{2,3}$.

Therefore, it is paramount to be informed about their composition, both mineralogical and physicochemical. characteristics, by the means of different techniques available for this purpose $e^{4,5}$.

In the cosmetic industry, clay minerals are often used as excipients to stabilize emulsions or suspensions and to modify the rheological behavior of these systems. They also play an important role as adsorbents or absorbents,

*e-mail: vsantos2@ucs.br. not only in cosmetics but also in other industries, such as pharmaceuticals ${ }^{6}$.

In general, minerals clays contain $\mathrm{Si}, \mathrm{Al}, \mathrm{Fe}, \mathrm{Ti}, \mathrm{Mg}$, $\mathrm{Ca}, \mathrm{K}, \mathrm{Na}$, as phyllosilicates, oxides, carbonates, kaolinite, chlorides, etc. The importance of these elements in the cosmetics field is based on the assumed role of various compounds on the skin, such as hematite $\left(\mathrm{Fe}_{2} \mathrm{O}_{3}\right)$ as pigment, opacifier, antiseptic and as a cell renewal catalyst., Phyllosilicates, vermiculite $(\mathrm{MgFe}, \mathrm{Al})_{3}(\mathrm{Al}, \mathrm{Si})_{4} \mathrm{O}_{10}(\mathrm{OH})_{2} \cdot 4 \mathrm{H}_{2} \mathrm{O}$, kaolinite $-\mathrm{Al}_{2} \mathrm{Si}_{2} \mathrm{O}_{5}(\mathrm{OH})_{4}$, as a diluent and binder, emulsifying, thickening and anticaking agent, flavor corrector, carrier releaser of active principles, providing reconstruction of skin tissues, hydration and a soothing effect, $\mathrm{ZnO}$ and $\mathrm{MgO}$ that are invigorating ${ }^{2}$. Titanium oxide (rutile) is a further compound of interest in cosmetology, chiefly employed in 
photo protection formulations because it provides reflection of UV radiation ${ }^{6}$.

Minerals are widely used in the pharmaceutical industry as lubricants, desiccants, disintegrating, diluents, binders, pigments, and opacifiers, as well as emulsifying, thickening, isotonic, agents, and anticaking agents, and flavor correctors and carriers of active ingredients ${ }^{6}$. In addition, also clays have been employed as carriers for organic molecules in cosmetics and drugs, as a catalyst support ${ }^{7}$ and as excipient in solid, liquid, and semi-solid pharmaceutical, such as gels, for example $e^{1,6,8,9}$. Gels are semisolid systems composed of two phases: the liquid dispersing phase and the solid dispersed phase ${ }^{10}$. There is a growing interest in the use of clays based on the search for abundant and low-priced materials that when disposed of do not harm the environment ${ }^{11}$. A variety of minerals are used as excipients in cosmetic preparations because they have certain desirable physical and physicochemical properties, such as high adsorption capacity, specific surface area, swelling capacity, and reactivity to acids. Other important properties are water solubility and dispersivity, hygroscopicity, unctuosity, thixotropy, slightly alkaline reaction $(\mathrm{pH})$, plasticity, opacity, and color ${ }^{12}$.

This work aims to characterize and decontaminate the clay from Tocantins/Brazil, here named Clay V, and to evaluate the incorporation viability of this substance in different concentrations into cosmetic formulations in gel form.

\section{Materials and Methods}

\subsection{Materials}

The clay sample (named Clay V) was collected in Tocantins (Brazil) in coordinates -9³2'48.04" $\mathrm{S}$, $48^{\circ} 24^{\prime}$ '01.49'W. According to the geological map (Figure 1), the collection region located in Folha Miracema do Norte identified as rocks of the Archaean basement belonging to the Rio do Coco Group, Neoproterozoic supracrustal rocks associated with the Cinturão Araguaia and Phanerozoic coverage related to the Paleozoic sedimentary rocks of the Parnaíba Basin ${ }^{13}$.

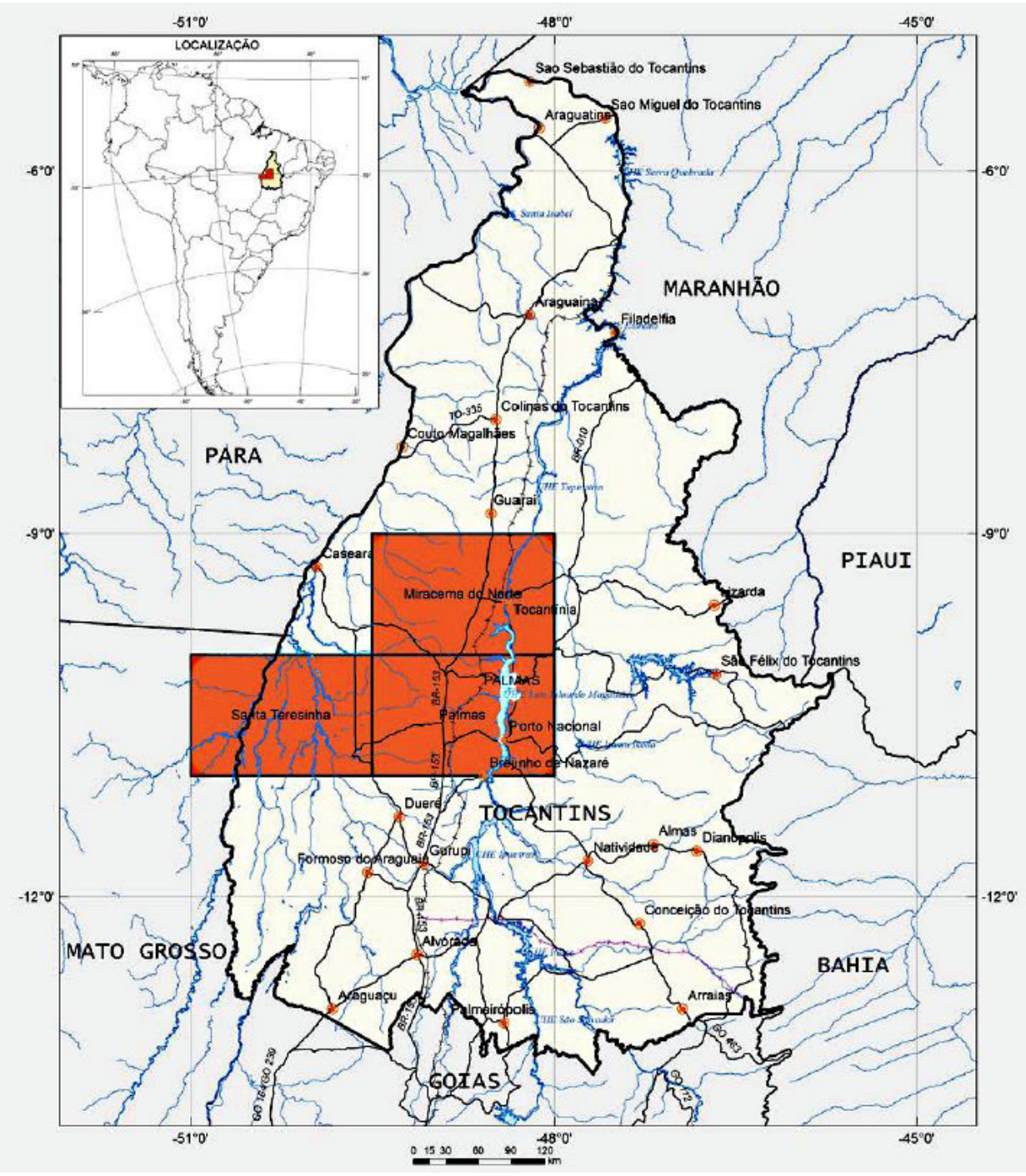

Figure 1. TO map addapted from Ribeiro and Alves ${ }^{13}$. 
The Pimenteiras Formation is represented by Devonian sediments of the Basin of the Parnaíba Basin and is constituted in a succession of fine and coarse sandstones, laminated siltstones and siltstones, argillaceous and conglomeratic and microconglomerate secondary levels. This formation is of marine origin, predominantly of shallow water and subordinated to two different environments. In the studied region, these rocks comprise partially reddish, fine-grained and also better sandstones ${ }^{13}$.

\subsubsection{Clay characterization}

\subsubsection{X-ray diffraction analysis}

Mineralogical analysis was carried out by X-ray diffraction (XRD). XRD patterns were obtained with a Siemens (BRUKER-AXS) D-5000 diffractometer (Germany) operating at $40 \mathrm{kV}$ and $40 \mathrm{~mA}$ using $\mathrm{Cu}-\mathrm{K} \alpha$ monochromatic radiation $(\lambda=1.5406 \AA)$, divergence and anti-scattering slits of $1^{\circ}$ and $0.2 \mathrm{~mm}$ detector slit. It was used for total rock analysis the angular range from 2 to $72^{\circ} 2 \theta$, scan speed of $0.02^{\circ} / 1 \mathrm{~s}$. For the oriented slides $(<2 \mu \mathrm{m}$ fraction) the angular range from 2 to $28^{\circ} 2 \theta$ was chosen, scan speed of $0.02^{\circ} / 2 \mathrm{~s}$ for natural $(\mathrm{N})$ and heated $(\mathrm{H})$ samples and $0.02^{\circ} / 3 \mathrm{~s}$ for glycolated sample $(\mathrm{G})$. The samples were prepared as it follows: unprocessed (raw), clay $\mathrm{V}$ was disaggregated by hand grinding to a fine powder with the use of agate mortar and pestle. Then, the disaggregated material was sieved through $74 \mathrm{m \mu}$ sieve. Finally, the obtained powder was mounted on a sample holder for subsequent analysis. After primary disaggregation of raw sample, the preparation procedure was followed by: (1) powdered material was dispersed in deionized water and stirred for continued 14 hours; (2) for further disaggregation ultrasonic probe was used for approximately 6 minutes; (3) the clay fraction $<2 \mu \mathrm{m}$ was separated following the Stokes's law which relates the settling velocity of a particle to its size and specific gravity. The sample was placed in a settling vessel and filled up with deionized water to complete the settling zone, then the temperature of the dispersion was measured $\left(24^{\circ} \mathrm{C}\right)$ and the vessel agitated. According to the calculation of the fluid viscosity, the sample was decanted for 4 hours and 21 minutes; at the end of the settlement time, the supernatant clay particles was quickly syphoned out to a beaker; (4) the supernatant material obtained from decantation was pipetted onto glass slides. It was used only enough sample to cover each slide; (5) the glass slides were allowed to dry at room temperature overnight. After dried the slides were ready for the XRD analysis.

\subsubsection{Chemical analysis}

Elemental chemical analysis was performed by X-ray fluorescence spectrometry (XRF) on a Rigaku RIX2000 (Japan) sequential spectrometer equipped with $\mathrm{Rh}$ X-ray Tube. Loss on ignition (LOI) was determined in accordance with ASTM D7348-08 method ${ }^{14}$.

\subsubsection{Thermal analysis}

Thermo gravimetric analysis (TGA/DTA) of Clay V was performed on a Netzsch, STA 449 F3 (Germany) thermo balance from ambient temperature $\left(25^{\circ} \mathrm{C}\right)$ until $800^{\circ} \mathrm{C}$, using a heating rate $10^{\circ} \mathrm{C} \cdot \mathrm{min}^{-1}$ under $\mathrm{N}_{2}$ atmosphere.

\subsubsection{Fourier Transform Infrared Spectroscopy (FTIR)}

Infrared spectra were obtained using a Nicolet IS10, Thermo Scientific spectrophotometer (USA) in the Attenuated Total Reflectance (ATR) mode, in the interval of $400-4,000 \mathrm{~cm}^{-1}$, 32 scans and $4 \mathrm{~cm}^{-1}$ resolution.

\subsubsection{Particle Size Distribution}

The granulometric analysis of the clay sample was performed, after decontamination, by the method of sieving, in order to determine the particle size distribution. The procedure consisted of firstly defragmenting the larger clusters of the sample using gral and pistil, and subsequently inserting the solid material to be analyzed in a sieve (Bertel brand) for 25 minutes with vibration 6 (medium speed). Six sieves and the collection bottom were used. The sieves used were of $707 \mathrm{mu}(710 \mu \mathrm{m}), 500 \mathrm{mu}(500 \mu \mathrm{m}), 420 \mathrm{mu}(425 \mu \mathrm{m})$, $354 \mathrm{mu}(355 \mu \mathrm{m}), 250 \mathrm{mu}(250 \mu \mathrm{m})$ and $177 \mathrm{mu}(180 \mu \mathrm{m})$.

\subsubsection{Raw sample preparation and microbial sterilization}

Before being used in the preparation of formulations, Clay V samples were oven dried (Tecnal, model TE-394/2) at $120^{\circ} \mathrm{C}$ during 24 hours. This sterilization process was based on the World Health Organization hand hygiene observation method ${ }^{15}$.

\subsubsection{Preparation and Characterization of Gel}

\subsubsection{Clay-gel preparation}

A hydrophilic gel of Aristoflex ${ }^{\circledR}$ AVC (Ammonium Acryloyldimethyltaurate/VP Copolymer) was prepared in concentrations of $1 \%, 3 \%$ and $5 \%(\mathrm{w} / \mathrm{w})$ of clay V. In parallel, a clay less gel was prepared, which was used as standard. The qualitative and quantitative composition of the gel is shown in Table 1.

Table 1. Description of the Aristoflex ${ }^{\circledast}$ gel formulation.

\begin{tabular}{lcccc}
\hline \multirow{2}{*}{ Component } & \multicolumn{4}{c}{ Concentration $(\% \mathrm{w} / \mathrm{w})$} \\
\cline { 2 - 5 } & $\mathrm{G}-\mathrm{P}$ & $\mathrm{G}-1 \%$ & $\mathrm{G}-3 \%$ & $\mathrm{G}-5 \%$ \\
\hline Aristoflex ${ }^{\circledR} \mathrm{AVC}$ & 0.50 & 0.50 & 0.50 & 0.50 \\
\hline Almond Oil & 1.50 & 1.50 & 1.50 & 0.05 \\
\hline Butylhydroxytoluene & 0.05 & 0.05 & 0.10 & 0.05 \\
\hline Propylparaben & 0.10 & 0.10 & 0.10 & 0.10 \\
\hline Methylparaben & 0.10 & 0.10 & 3.00 & 5.10 \\
\hline Clay V & 0.00 & 1.00 & 94.75 & 92.75 \\
\hline Water & 97.75 & 96.75 & & 0 \\
\hline
\end{tabular}


Aristoflex ${ }^{\circledR}$ AVC was weighed and dispersed in a part of distilled water. Methylparaben was dissolved in another portion of heated water $\left(50^{\circ} \mathrm{C}\right)$ under stirring. In another vessel, the oil, butylhydroxytoluene (BHT) and propylparaben were mixed under stirring. Both aqueous and oily solutions were incorporated into the gel and the final blend was allowed to rest for 24 hours. The granulometric range of Clay $\mathrm{V}$ used was $\leq 180 \mu \mathrm{m}$. This granulometry was selected because it is a size range that provides greater adhesiveness and better cutaneous sensorial. Clay V was dispersed in glycerin, and the pre-prepared gel was slowly added over this dispersion. $100 \mathrm{~g}$ of each formulation were divided into three $20 \mathrm{~g}$ units, packed at room temperature $\left(20^{\circ} \mathrm{C} \pm 2\right)$ in polyethylene bottles.

\subsubsection{Control quality of clay-gel formulations}

All the tests were done in triplicate, and the results corresponded to the average of the three verifications, except the organoleptic analyzes and the centrifugation because they were visual.

\subsubsection{Organoleptic Analysis}

Sensory analysis was performed with visual verification of color, odor, appearance and texture of the gel ${ }^{16,17}$.

\subsubsection{4 $\mathrm{pH}$ determination}

The $\mathrm{pH}$ of the samples was read by dispersing the sample in distilled water $(10 \%, \mathrm{v} / \mathrm{v})$ at $25^{\circ} \mathrm{C}$ in potentiometer (Micronal/model B474), calibrated with $\mathrm{pH} 4.0$ and 7.0 solutions ${ }^{18}$.

\subsubsection{Viscosity Measurements}

Viscosity was determined by measurements on a digital viscometer (Mars /model MVD-20) using spindle 4. The spindle rotational speeds were 3, 6 and $9 \mathrm{rpm}$, increasing and decreasing, and the temperature of work was $20^{\circ} \mathrm{C} \pm 2$.

\subsubsection{Spreadability determination}

The spreadability determination was performed according to the methodology described by the literature ${ }^{19}$. The results were expressed as spreadability of the sample as a function of the applied weight, according to Equation 1.

$$
E i=d^{2} \cdot \frac{\pi}{4}
$$

Considering: $\mathrm{Ei}=$ spreadability of the sample for a given weight $\mathrm{i}\left(\mathrm{mm}^{2}\right) ; \mathrm{d}=$ average diameter $(\mathrm{mm})$.

\subsubsection{Centrifugation Test}

The centrifugation procedure consisted of inserting $1 \mathrm{~g}$ of the sample into a graduated conical test tube and introducing the tube in the centrifuge (ALC brand, model PK131) to the cycle of $3000 \mathrm{rpm}$ for 30 minutes at room temperature.

\section{Results and Discussion}

\subsection{Mineralogical composition}

\subsubsection{X-ray diffraction}

Clay minerals are phyllosilicates containing two types of sheets, structurally organized in units named tetrahedral sheet $(\mathrm{T})$ and octahedral sheet $(\mathrm{O})$. The cations present in each sheet and the substitutions in them may lead to a net charge deficit that can depend on the type of sheet ( $\mathrm{T}$ or $\mathrm{O}$ ) and on the type of substituting cations (the substitutions are basically driven by the ion size, charge and other atomic properties). The type of substitution affects the behavior of the clay in regard to adsorption capacity and rheological properties ${ }^{1}$. The utility of a clay mineral in specific applications are due to their physical and chemical properties, which are mainly dependent on two factors: (a) their crystal structure, which can be either a 1:1 structure (one tetrahedral sheet bound to another octahedral sheet) or a 2:1 structure (one octahedral sheet between two tetrahedral sheet) and (b) their chemical composition $^{3,10}$.

The determination of the crystalline phases of clay minerals present in a sample is very important before their application as raw material constituting an end product. Figure 2 shows the XRD patterns of Clay V. It can be seen on diffractogram, Figure 2 (a), the presence of vermiculite (peak at $14.15^{\circ}$ in the Handbook of Mineralogy), mica/illite $\left(\mathrm{K}, \mathrm{H}_{3} \mathrm{O}\right)(\mathrm{Al}, \mathrm{Mg}, \mathrm{Fe})_{2}(\mathrm{Si}, \mathrm{Al})_{4} \mathrm{O}_{10}\left[(\mathrm{OH})_{2}, \mathrm{H}_{2} \mathrm{O}\right]$, kaolinite $\left[\mathrm{Al}_{2} \mathrm{Si}_{2} \mathrm{O}_{5}(\mathrm{OH})_{4}\right]$ reflections were observed ${ }^{20}$, quartz $^{21}$ and plagioclase. In Figure 2 (b) the oriented slides is shown. It is possible to verify that the peak of vermiculite after heating shifts to the same position of illite. No expandable clay minerals were observed on glycolated analysis. Mica is no longer visible on oriented slides due the $<2 \mu \mathrm{m}$ fraction that was analyzed. It is known that clays with kaolinite and illite have already been used in the cosmetic composition ${ }^{5}$.

\subsubsection{Chemical Composition}

Table 2 shows the components of the Clay V sample as well as their percentages in relation to the total mass obtained by XRF. The results found show that the clay is composed mainly of silica (55.80) and alumina $22.66 \%$ in the composition. The other compounds present in the sample are in very small proportions. The composition found is confirmed by the presence of kaolinite, illite, vermiculite and quartz phases according to the XRD results.

The chemical composition of a mineral directly influences the function it will perform in a product. A clay containing silica has as main cosmetic functions moisturizing, reconstitution of tissues and reduction of inflammations. Silica may be in crystalline form (quartz) or non-crystalline form (amorphous) ${ }^{3}$. In case of crystalline form, which was identified in Clay V, studies describing the toxic potential of this component can be found in the literature. Long-term inhalation studies of rats and mice have shown that quartz particles produce cellular proliferation, nodule formation, suppressed immune functions, and alveolar proteinosis. Experimental studies of rats reported the occurrence of adenocarcinomas and squamous cell carcinomas after the inhalation or intratracheal instillation of quartz ${ }^{22}$.

Problems regarding to quartz toxicity are related to the inhalation of this substance, and it should still be taken into consideration the inhaled dose and the degree of exposure of the quartz user. In case of applying Clay $\mathrm{V}$ in cosmetic products, the risk of toxicity to the user may occur through an accidental inhalation of products such as talcum powder, makeup and other presentations in the form of powder. In the case of gel, a semi-solid pharmaceutical form (there 


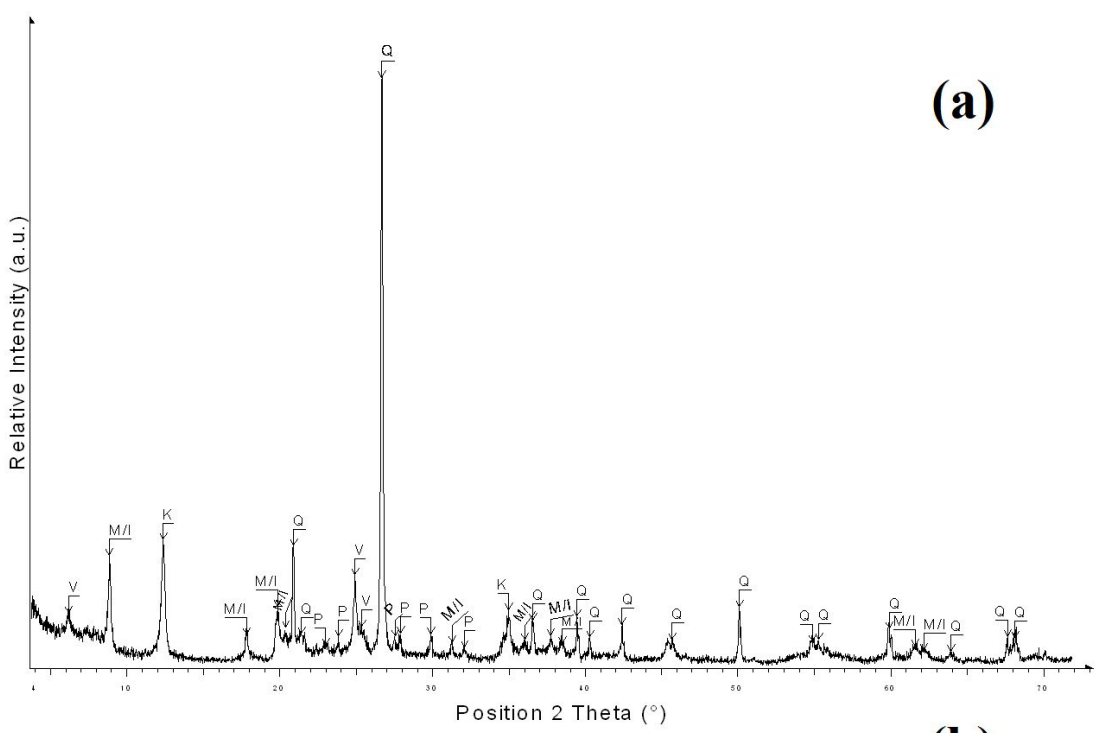

(b)

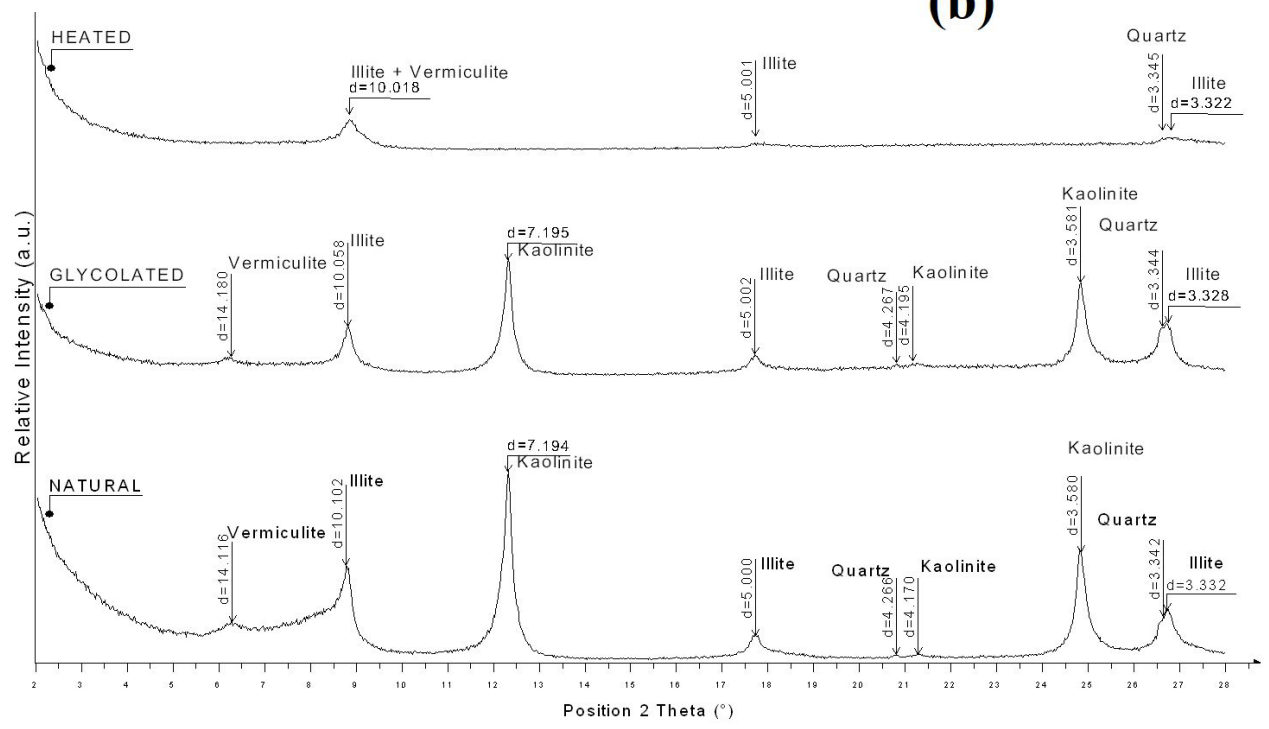

Figure 2. XRD patterns of Clay V (a) Total Rock and (b) oriented slides $<2 \mu \mathrm{m}$ fraction.

Table 2. Chemical composition for Clay V (oxide wt.\%).

\begin{tabular}{ccccccccccccc}
\hline Oxide & $\mathrm{SiO}_{2}$ & $\mathrm{Al}_{2} \mathrm{O}_{3}$ & $\mathrm{Fe}_{2} \mathrm{O}_{3}$ & $\mathrm{~K}_{2} \mathrm{O}$ & $\mathrm{TiO}_{2}$ & $\mathrm{MgO}$ & $\mathrm{P}_{2} \mathrm{O}_{5}$ & $\mathrm{MnO}$ & $\mathrm{Cr}_{2} \mathrm{O}_{3}$ & $\mathrm{SrO}$ & $\mathrm{ZnO}$ & $\mathrm{LOI}$ \\
\hline$\%$ (wt) & 55.80 & 22.66 & 5.90 & 3.61 & 1.15 & 2.20 & 0.08 & 0.02 & 0.03 & 0.02 & 0.02 & 7.52 \\
\hline
\end{tabular}

is no aerosol release) where the application form is topical the risk of inhalation is non-existent. However, studies that evaluate the degree of quartz penetration on the skin and a possible absorption of this element by the cutaneous via are interesting, but they are not part of the scope of this work. Alumina has a moisturizing, antiseptic, astringent and healing ${ }^{12}$. Therefore, the presence of this element in the composition of Clay 5 may suggest these resources for this raw material.

Previous studies have already analyzed chemical composition of clay minerals used in cosmetic formulations. In one of these studies, 4 clays containing kaolinite and illite were evaluated and had silica content of $48.1 \%$,
$53.4 \%, 55.8 \%$ and $54.6 \%$, respectively, and alumina content of $28.0 \% 27.5 \%, 26.0$ and $26.0 \%$, respectively. Clay V, for having higher silica content, has cosmetic functions of moisturizing, reconstitution of tissues and reduction of inflammations more notable $\mathrm{e}^{23}$.

\subsubsection{Thermal characteristics}

The Figure 3 shows the thermal characteristics of Clay V.

TGA/DTG curves of Clay V sample showed mass loss in the temperature range of $60^{\circ} \mathrm{C}$ and $220^{\circ} \mathrm{C}$ of the order of $1.55 \%$, suggesting that this loss was due to release of water molecules trapped at clay surface. An inflection point 


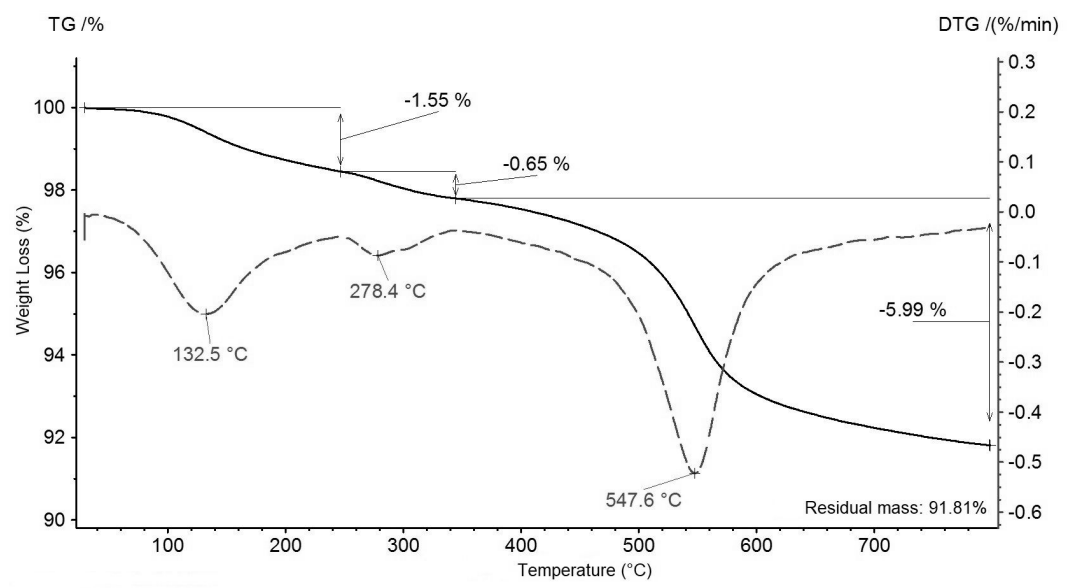

Figure 3. Thermogravimetric curves of the samples: Thermogravimetric Analysis (TG) and Differential Thermal Analysis (DTG).

Table 3. FTIR frequencies and assignment in clay V.

\begin{tabular}{cc}
\hline $\begin{array}{c}\text { Wavenumber } \\
\left(\mathrm{cm}^{-1}\right)\end{array}$ & Assignment ${ }^{20,24-34}$ \\
\hline 3700 & $v_{\text {O-H }}$ \\
\hline 3652 & \\
\hline 3621 & \\
\hline 3526 & $\delta_{\text {O-H }}$ \\
\hline 3441 & $v_{\text {Si-O }}$ \\
\hline 1638 & \\
\hline 1114 & $\delta_{\text {Al-OH-Al }}$ \\
\hline 1029 & \\
\hline 1006 & $v_{\text {Si-o }}($ quartz) \\
\hline 934 & \\
\hline 913 & \\
\hline 837 & \\
\hline 797 & \\
\hline 780 & \\
\hline 695 & \\
\hline 538 & \\
\hline 471 & \\
\hline 430 & \\
\hline
\end{tabular}

occurred at $278.4^{\circ} \mathrm{C}$ in the thermal balance curve $(0.65 \%)$ followed by dehydroxylation at $547.6^{\circ} \mathrm{C}(5.99 \%)^{24}$.

\subsubsection{Fourier Transform Infrared Spectroscopy (FTIR)}

The infrared spectra (Figure $4 \mathrm{a}, 4 \mathrm{~b}$ and Table 3 ) contained kaolinite, illite, vermiculite and quartz, according to XRD.

The $\mathrm{O}-\mathrm{H}$ asymmetric stretching occurs around $3700 \mathrm{~cm}^{-1}$, probably as a result of the presence of the surface and internal $\mathrm{OH}$ groups of the $\mathrm{Al}-\mathrm{OH}$ in the octahedral sheets. The band at $3660 \mathrm{~cm}^{-1}$ is attributed to water $\mathrm{OH}$ bending vibrations $^{32}$. Bands at $3700 \mathrm{~cm}^{-1}$ and $3652 \mathrm{~cm}^{-1}$ can be assigned to the stretching vibration of vermiculite structural $\mathrm{O}-\mathrm{H}$ bonds. Both these bands are related to vibration of the $\mathrm{O}-\mathrm{H}$ bond associated to interlayer cations ${ }^{33}$. The broad band
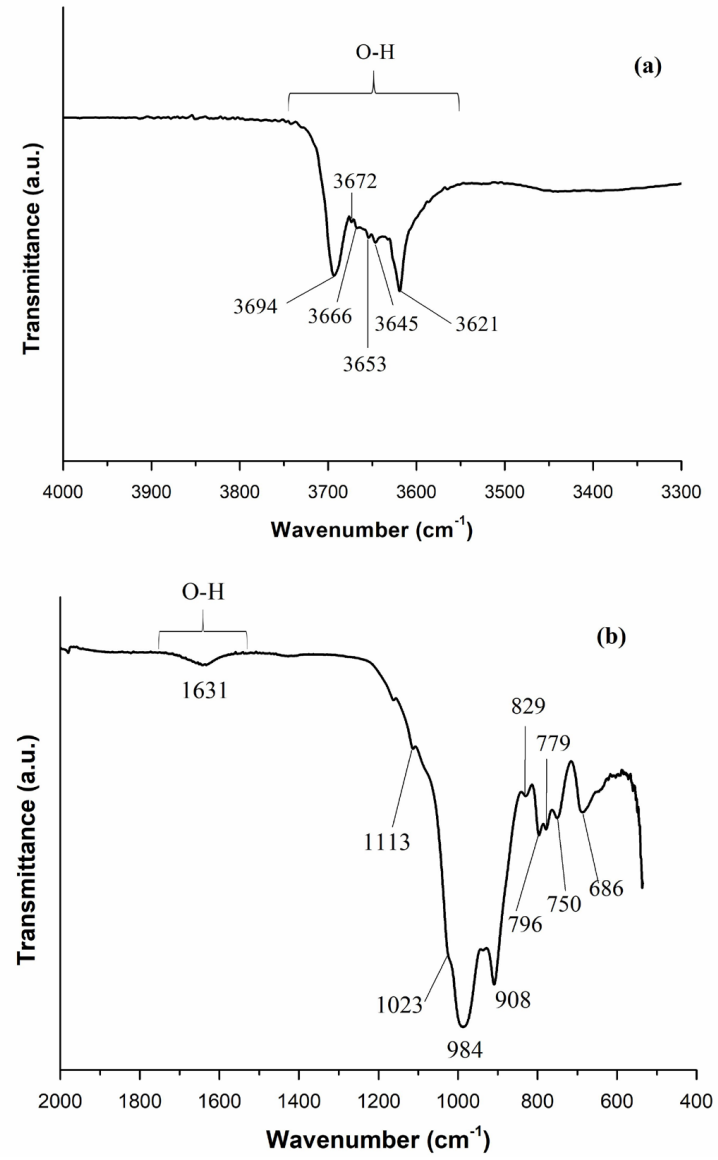

Figure 4. Infrared spectra for clay V: (a) region between 4000 and $3300 \mathrm{~cm}^{-1}$; (b) region below 1900 to $400 \mathrm{~cm}^{-1}$.

at $3400 \mathrm{~cm}^{-1}$ is attributed to stretching vibrations of $\mathrm{O}-\mathrm{H}$ bonds of water. The last band related to vibration of $\mathrm{O}-\mathrm{H}$ bond is spectral band at $1638 \mathrm{~cm}^{-1}$ (deformation vibration of $\mathrm{O}-\mathrm{H}$ bonds of water). Intense bands in 1029 and $1006 \mathrm{~cm}^{-1}$ is due to stretching vibration of $\mathrm{Si}-\mathrm{O}$ bonds of vermiculites, this band can be assigned to stretching vibration of $\mathrm{Si}-\mathrm{O}$ 
bonds of amorphous silica. The weak bands at $780 \mathrm{~cm}^{-1}$, $695 \mathrm{~cm}^{-1}$ and $538 \mathrm{~cm}^{-1}$ are related to in plane deformation vibration of Al-O-Si bonds of vermiculites; band at $538 \mathrm{~cm}^{-1}$ is seen as shoulder in intensive band at $430 \mathrm{~cm}^{-1}$. Intense band at $430 \mathrm{~cm}^{-1}$ can be assignment to deformation vibration of $\mathrm{Si}-\mathrm{O}-\mathrm{Si}$ bonds of vermiculites ${ }^{31}$.

For kaolinite the band at $3621 \mathrm{~cm}^{-1}$ is the inner $\mathrm{OH}$ vibrational mode. Between 1100 and $400 \mathrm{~cm}^{-1}$ there were kaolinite $\mathrm{Si}-\mathrm{O}$ bands. Bands at 934 and $913 \mathrm{~cm}^{-1}$ corresponded to bending modes of the $\mathrm{Al}-\mathrm{OH}-\mathrm{Al}^{24,25,27,30}$. The illite shows bands 3652 and $3621 \mathrm{~cm}^{-1}$, at $3652 \mathrm{~cm}^{-1}$ region occurred overlapping bands from both the kaolinite and illite ${ }^{20,29}$. The absorption band at $1638 \mathrm{~cm}^{-1}$ was related to the water $\mathrm{OH}$ bending mode $26,27,28,29$. The bands at $797 \mathrm{~cm}^{-1}$, $780 \mathrm{~cm}^{-1}$ and $695 \mathrm{~cm}^{-1}$ are typical for quartz ${ }^{34}$.

\subsubsection{Particle size distribution}

Figure 5 shows the particle size distribution of clay particles. The largest fraction retained in the sieves was of particles larger than $710 \mu \mathrm{m}(63.22 \%)$. The second largest fraction was of particles smaller than $180 \mu \mathrm{m}(9.70 \%)$ - which was the fraction used for incorporation into the gel. This size range $(0-180 \mu \mathrm{m})$ was chosen since small size particles provide better sensory to the product and adhesiveness to the skin.

The granulometry of a material is a very important property that must be known for the application in cosmetics, since according to the size of the particles, the purpose of the product is different. Raw materials with high granulometry are usually exploited by their exfoliating action, while those with fine granulometry are used for skin hydration because they have greater adhesiveness and more pleasant sensory to the $\operatorname{skin}^{35}$. Therefore considering the above described the clays in the cosmetology area can be used as exfoliating or moisturizing. In the present work it was chosen to work

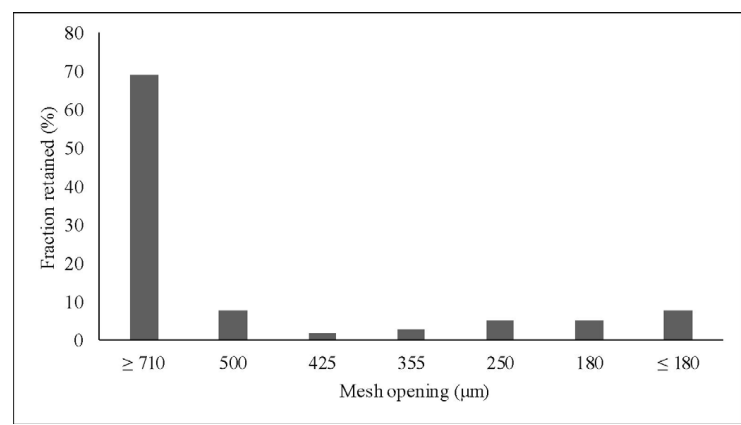

Figure 5. Granulometric distribution of clay. with the lower particle size, although the retained fraction of the clay in the $0-180 \mu \mathrm{m}$ range was low $(9.70 \%)$. It was decided to work with the lowest particle size and not with the largest retained fraction as the aim was to evaluate the incorporation of clays in cosmetic formulations for moisturizing use. In addition, products currently on the market, such as bentonite, consist of fine-grained powder (no more than $0.5 \%$ particles larger than $75 \mu \mathrm{m}$ ), aggregates are usually 50-300 $\mu \mathrm{m}$, although the individual particles making them up is not over $2 \mu \mathrm{m}^{1}$.

It is known that in terms of process, choosing to work with the smallest particle size range will involve a particle size reduction step that may imply higher cost of production. However, in this first moment, the optimization of the granulometric separation process of clay was not the focus of study in this work, but in later studies with this raw material.

\subsubsection{Microbiological assessment}

In Table 4, the results of the microbiological analysis obtained after the sample sterilization process by dry heat are described. The sample, in all analyzed items, is in compliance with the microbiological parameters for Personal Hygiene Products, Cosmetics and Perfumes established by the Brazilian cosmetics legislation, Resolution 481/1936, which are the same as those defined by the British Pharmacopoeia ${ }^{37}$.

Facing these results, it was verified that the procedure used for the sterilization of the sample was effective. The dry heat method allowed the sterilization of the sample by the high temperature. Previous studies ${ }^{38}$ point out that dry heat methodology (physical method) is more indicated than ethanol sterilization (chemical method), mainly because it does not use solvents, avoiding the generation of effluents and waste.

In a previous work ${ }^{23}$, clay samples were microbiologically evaluated right after being collected from the environment. The results obtained by this research indicated high concentration of microorganisms in the samples, therefore, the need for decontamination of clays became mandatory.

\subsection{Characterization of gels containing clay}

\subsubsection{Control quality of clay-gel formulations}

Gels are vehicles widely used in cosmetology for the incorporation of assets. Hydrophilic gels as the one prepared in this study make the product sensibly pleasant in the application and are suitable for people who have oily skin. The gels are characterized by the fact that they can be distributed readily on the skin. After the product application only very little residue

Table 4. Results of microbiological analysis.

\begin{tabular}{|c|c|c|}
\hline Assay & Result & Specification $^{36}$ \\
\hline Count of Mesophilic Bacteria & $\begin{array}{c}1.3 \times 10^{2} \mathrm{UFC} / \mathrm{g} \\
(\text { est })\end{array}$ & $\begin{array}{c}\text { Maximum } \\
5.0 \times 10^{3} \mathrm{UFC} / \mathrm{g}\end{array}$ \\
\hline Mold Yeast Count & $\begin{array}{c}<1.0 \times 10^{1} \mathrm{UFC} / \mathrm{g} \\
(\text { est })\end{array}$ & $\begin{array}{c}\text { Maximum } \\
5.0 \times 10^{3} \mathrm{UFC} / \mathrm{g}\end{array}$ \\
\hline Fecal Coliforms & Absence in $1 \mathrm{~g}$ & Absence in $1 \mathrm{~g}$ \\
\hline Total Coliforms & Absence in $1 \mathrm{~g}$ & Absence in $1 \mathrm{~g}$ \\
\hline Search for Escherichia coli & Absence in $1 \mathrm{~g}$ & Absence in $1 \mathrm{~g}$ \\
\hline Search for Pseudomonas aeruginosa & Absence in $1 \mathrm{~g}$ & Absence in $1 \mathrm{~g}$ \\
\hline Search for Staphylococcus aureus & Absence in $1 \mathrm{~g}$ & Absence in $1 \mathrm{~g}$ \\
\hline
\end{tabular}


Table 5. Organoleptic characteristics.

\begin{tabular}{ccccc}
\hline Sample & Color & Odor & Aspect & Texture \\
\hline G-P & Colorless & Characteristic of gel & Homogeneous & Soft and refreshing \\
\hline G-1\% & Light brown & Characteristic of gel & Homogeneous & Soft and refreshing \\
\hline G-3\% & Medium brown & Characteristic of gel & Homogeneous & Soft and refreshing \\
\hline G-5\% & Dark brown & Characteristic of gel & Homogeneous & Soft and refreshing \\
\hline
\end{tabular}

should remain on the skin. Gels generally comprise a relatively high proportion of hydrophilic gelling substance and the gelling has a significant influence on the sensory properties of the product. The common gelling systems either cannot be readily distributed on the skin, do not give a feeling of freshness or leave behind too sticky a residue on the skin. To improve these sensory problems related to traditional gellings, new generation thickeners such as Aristoflex AVC, are being used in the preparation of gels. Aristoflex AVC not contain carbohydrates and aromatic solvents. It is used as gelling substance in aqueous systems and thickening agent in emulsions of "o/w". The stabilizing effect of "Aristoflex AVC" is explained by the structure of the polymer: Gel coats droplets or solids (e.g., pigments). "Aristoflex AVC" is a copolymer, which due to its hydrophobic linkers is used as an effective combining agent. In addition, due to the hydrophilic sulfo groups the polymer interacts with biologically active substances formulations and prolongs their action retaining them on the skin surface longer ${ }^{39}$.

Therefore, it is recommended to use "Aristoflex AVC" in products for aging skin, as well as for treating blepharitis and demodicosis. Recommended amount of "Aristoflex AVC" is $0.5-1.5 \%$.

Thus, for the advantages that the Aristoflex AVC present, they were the gelling substance chosen in this study to prepare the gel and to evaluate the potential of incorporation of the clay (Clay V) in cosmetic vehicles. It is known that there is often the impossibility of associating assets in vehicles, as these can generate destabilization of the system, for example, increasing or decreasing the viscosity, cause agglomeration and coagulation of gels, turbidity, among other changes that can be technological limitations on the use of an asset. The concentrations of clay tested (1,3 and 5\%) were chosen based on the products currently on the market that contain clay in their composition and that have a clay concentration range of $1-5 \%$.

\subsubsection{Organoleptic evaluation}

The organoleptic characteristics of a cosmetic product are important because they can help detecting instabilities in formulations. Table 5 represents the organoleptic characteristics observed for the different formulations prepared. For all organoleptic parameters tested, the gels showed characteristics compatible with those of dispersed systems. The coloring intensities presented by the samples corresponded to the amount of clay added. The higher the concentration of clay, the darker the formulation.

It is observed that the incorporation of Clay $\mathrm{V}$ in the cosmetic gel formulation did not change macroscopic aspects of the product, which is a positive point, since any modification could make the cosmetic less attractive to the consumer.

\subsection{3 pH determination}

The skin of the facial region presents $\mathrm{pH}$ values ranging from 5.5 to 6.5 , defined by internal and external factors ${ }^{41}$.
Table 6. $\mathrm{pH}$ values of gels G-P, G- $1 \%$, G-3\% and G-5\%.

\begin{tabular}{cc}
\hline Sample & Average $\mathrm{pH}$ \\
\hline $\mathrm{G}-\mathrm{P}$ & $5.74 \pm 0.097$ \\
\hline $\mathrm{G}-1 \%$ & $5.99 \pm 0.108$ \\
\hline $\mathrm{G}-3 \%$ & $6.00 \pm 0.051$ \\
\hline $\mathrm{G}-5 \%$ & $5.92 \pm 0.044$ \\
\hline
\end{tabular}

G-P: standard gel; G-1\%: gel within clay $1 \%$; G-3\%: gel within clay $3 \%$ and G-5\%: gel within clay 5\%; Knowing the $\mathrm{pH}$ of a formulation is extremely important, since inadequate values may indicate chemical changes of the constituent elements. Changes in the product occur mainly due to the oxidation of some of the components present in the formulation ${ }^{42}$, which, in turn, can alter only the visual characteristics of the product or impair their effectiveness.

Therefore, cosmetic formulations of facial skin application must present a $\mathrm{pH}$ within this range.

The averages of the results obtained for the $\mathrm{pH}$ determination of the formulations, performed in triplicate, are shown in Table 6. It was observed that all gels presented $\mathrm{pH}$ values are within the range suitable for facial application.

\subsubsection{Viscosity assessment}

Figure 6 shows the average viscosity of the gels, determined in triplicate. By the analysis of the viscosity graph as a function of the shear rate, it was verified that all formulations showed a pseudoplastic behavior, which is evidenced by the reduction of the viscosity values as the shear increases. Thus, it can be said that the clay did not modify the rheological behavior of the Aristoflex ${ }^{\circledR}$ gel (G-P). The gels prepared can be classified as non-Newtonian fluids, since they have viscosity variation according to the shear rate, but without a linear relationship ${ }^{43}$. The pseudoplastic characteristic is ideal in cosmetic formulations, since it prevents the dispersed phase from moving ${ }^{44}$. The addition of Clay V did not cause rheological changes in the product, which ensures that it can be associated with the vehicle in question without hindering its use. It was observed, Figure 7 , an increase in the viscosity of the samples as the clay concentration was increased, $1 \%, 3 \%$ and $5 \%(\mathrm{w} / \mathrm{w})$. According to the literature, this phenomenon has already been observed in other studies ${ }^{10}$. Clays that present kaolinite generate a viscosity increase in aqueous dispersions ${ }^{41}$. This occurs due to the dilating flux caused by interactions between the dispersed particles during the shear.

\subsubsection{Spreadability determination}

Figure 7 shows the behavior of the gels regarding to the spreadability, with the average values obtained from the triplicates. The larger the diameter reached by the sample in the application of the technique, the greater the spreadability. All gels showed maximum spreadability greater than $2000 \mathrm{~mm}^{2}$. 


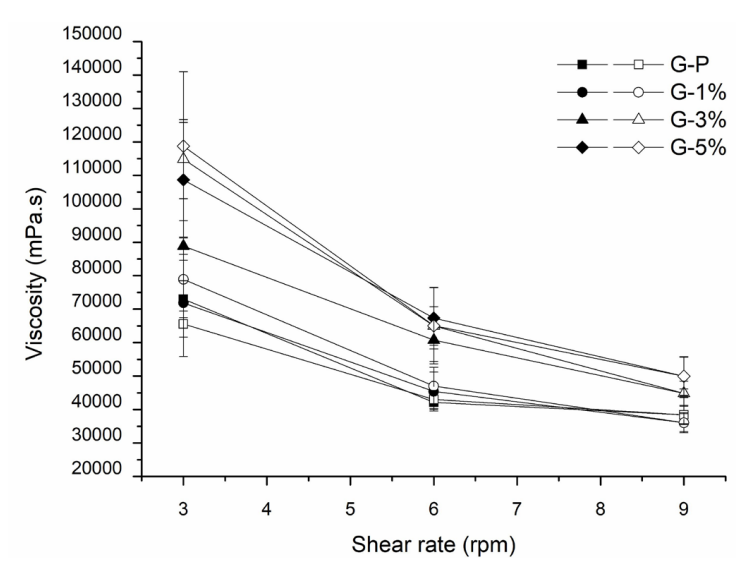

Figure 6. Viscosity of the gels (G-P: standard gel; G-1\%: gel within clay $1 \%$; G-3\%: gel within clay $3 \%$; G-5\%: gel within clay $5 \%$. Filled in symbol: going; Blank symbol: return).

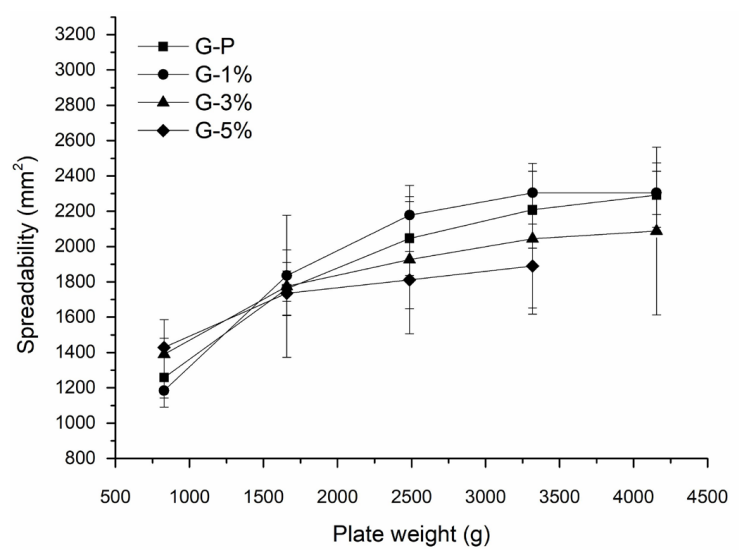

Figure 7. Gels spreadability (G-P: standard gel; G-1\%: gel within clay $1 \%$; G-3\%: gel within clay 3\%; G-5\%: gel within clay $5 \%$ ).

The spreadability test of a cosmetic product evaluates its expansion content on a contact surface. Good spreadability is essential for a formulation since it facilitates application and ensures even distribution, which influences the penetration of the active principle and the effectiveness of the product. In addition, the result is important for the market acceptance, since the consumer searches for cosmetics that present easy distribution on the $\operatorname{skin}^{45}$.

\subsubsection{Centrifugation test}

The incorporation of assets in cosmetic vehicles can often cause the destabilization of the system, causing product heterogeneity and its instability. Centrifugation is a physical method to prompt evaluates possible changes that may occur with the product, since the conditions created simulate an increase in the force of gravity, allowing and anticipating possible changes in stability. These changes can be observed in the form of precipitates, occurrence of phase separation, formation of compact sediments (caking), and coalescence, among others. In the case of the gels under study, the aim was to verify the presence of precipitates of clay or phase separation of the system ${ }^{46}$.

The gels developed, when submitted to centrifugation, proved the stability of the formulation. No formulation presented sediments formed by the clay, and the dispersed systems do not experience phase separation. All formulations behaved with no flocculation, precipitation and phase separation. With the result observed, the non-existence of physical instabilities of these systems was confirmed.

Opposite results were found by previous research, in which centrifugation tests were performed with 3 samples of facial masks containing clay, and all showed phase separation, showing to be visually unstable ${ }^{47}$. Therefore, the formulation developed in this study with Clay V is more stable and has better interactions between the components.

\section{Conclusion}

Regarding the chemical composition, the clay can be used as a moisturizer, inflammations reducer, antiseptic, astringent and healer.

The results obtained for the characterization of the gel, under the conditions tested, containing the different concentrations of Clay $\mathrm{V}$ showed that regardless of the concentration used the physical characteristics of the gels were not altered. This information is important in the development of a cosmetic because it allows indicating the maximum concentration of Clay $\mathrm{V}$ that can be added to the gel without harm to the final product.

The vehicle used is traditional in the cosmetic and pharmaceutical fields, what is innovative is the clay. Therefore, it was proven that Clay $\mathrm{V}$, which was characterized by some techniques, can be incorporated into the tested vehicle. The concern is that often these clays are difficult to be associated with vehicles, as they can cause rheological changes that hinder use, or alter macroscopic aspects that do not become attractive to the consumer.

Thus, it was confirmed that the clay under study can be incorporated into formulations as gels, as a great option to be used as an active principle. In addition, Clay $\mathrm{V}$ has potential for continuity regarding research and its application in other cosmetic vehicles.

\section{Acknowledgements}

Authors are beholden to the University of Caxias do Sul (UCS), to Federal University of Rio Grande do Sul (UFRGS) and to the Research Support Foundation of the Rio Grande do Sul State (FAPERGS) for financial support.

\section{References}

1. López-Galindo A, Viseras C, Cerezo P. Compositional, technical and safety specifications of clays to be used as pharmaceutical and cosmetic products. Appl Clay Sci. 2007;36:51-63. http:// dx.doi.org/10.1016/j.clay.2006.06.016.

2. Gomes CSF, Silva JBP. Minerals and clay in medical geology. Appl Clay Sci. 2007;36:4-21. http://dx.doi.org/10.1016/j. clay.2006.08.006.

3. Carretero MI, Pozo M. Clay and non-clay minerals in the pharmaceutical and cosmetic industries Part II. Active ingredients. Appl Clay Sci. 2010;47:171-81. http://dx.doi.org/10.1016/j. clay.2009.10.016.

4. Carretero MI, Pozo M, Legido JL, Fernández-González MV, Delgado R, Gómez I, et al. Assessment of three Spanish clays for their use in pelotherapy. Appl Clay Sci. 2014;99:131-43. http://dx.doi.org/10.1016/j.clay.2014.06.022. 
5. Khiari I, Mefteh S, Sánchez-Espejo R, Cerezo P, Aguzzi C, López-Galindo A, et al. Study of traditional Tunisian medina clays used in therapeutic and cosmetic mud-packs. Appl Clay Sci. 2014;101:141-8. http://dx.doi.org/10.1016/j.clay.2014.07.029.

6. Carretero MI, Pozo M. Clay and non-clay minerals in the pharmaceutical industry: part I. Excipients and medical applications. Appl Clay Sci. 2009;46(1):73-80. http://dx.doi. org/10.1016/j.clay.2009.07.017.

7. Zhang D, Zhou C, Lin C, Tong D, Yu W. Synthesis of clay minerals. Appl Clay Sci. 2010;50:1-11. http://dx.doi.org/10.1016/j. clay.2010.06.019.

8. Carretero MI. Clay minerals and their beneficial effects upon human health. a review. Appl Clay Sci. 2002;21:155-63. http:// dx.doi.org/10.1016/S0169-1317(01)00085-0.

9. Carretero MI, Legaly G. Clays and health: an introduction. Appl Clay Sci. 2007;36:1-3. http://dx.doi.org/10.1016/j. clay.2006.09.001.

10. Viseras C, Aguzzi C, Cerezo P, Lopez-Galindo A. Uses of clay minerals in semisolid health care and therapeutic products. Appl Clay Sci. 2007;36:37-50. http://dx.doi.org/10.1016/j. clay.2006.07.006.

11. Bergaya F, Lagaly G. General introduction: clays, clay minerals, and clay science. In: Bergaya F, Theng BKG, Lagaly G. Handbook of clay science. Amsterdam: Elsevier; 2006. p. 1-18.

12. Moraes JDD, Bertolino SRA, Cuffini SL, Ducart DF, Bretzke PE, Leonardi GR. Clay minerals: properties and applications to dermocosmetic products and perspectives of natural raw materials for therapeutic purposes - a review. Int J Pharm. 2017;534:213-9. http://dx.doi.org/10.1016/j.ijpharm.2017.10.031.

13. Ribeiro PSE, Alves CL. Geology and Mineral Resources of the Region of Palmas. Folha Miracema do Norte (SC.22-X-D), National Port (SC.22-Z-B) and Santa Teresinha (SC.22-Z-a) [map]. Goiânia: CPRM; 2017. Scale 1: 250,000.

14. ASTM: American Society for Testing Materials. ASTM D734808: Standard Test Methods for Loss on Ignition (LOI) of Solid Combustion Residues. West Conshohocken: ASTM; 2008.

15. Sax H, Allegranzi B, Chratti M, Boyce J, Larson E, Pittet D. The World Health Organization hand hygiene observation method. Am J Infect Control. 2009;37(10):827-34. http://dx.doi. org/10.1016/j.ajic.2009.07.003.

16. Lange MK, Heberlé G, Milán D. Evaluation of the stability and antioxidant activity of a non-ionic base emulsion containing resveratrol. Braz J Pharm Sci. 2009;45(1):145-51. http://dx.doi. org/10.1590/S1984-82502009000100018.

17. Dário GM, Silva GG, Gonçalves DL, Silveira P, Teixeria A Jr, Angioletto E, et al. Evaluation of the healing activity of therapeuticclay in rat skin wounds. Mater Sci Eng C. 2014;(43):109-16. http://dx.doi.org/10.1016/j.msec.2014.06.024.

18. Davis HM. Analysis of creams and lotions. In: Sensel AJ, editor. Newburger's manual of cosmetic analysis. Washington: Association Official Analytical Chemists; 1977. p. 32.

19. Knorst MT. Technological development of plastic pharmaceutical form containing concentrated extract of Achyrocline satureioides (Lam.) DC. Compositae (marcela) [dissertation]. Porto Alegre: Universidade Federal do Rio Grande do Sul; 1991.

20. Hammami-Ben Zaied F, Abidi R, Slim-Slim N, Somarin AK. Potentiality of clay raw materials from Gram area (Northern Tunisia) in the ceramic industry. Appl Clay Sci. 2015;112113:1-9. http://dx.doi.org/10.1016/j.clay.2015.03.027.

21. Mattioli M, Giardini L, Roselli C, Desideri D. Mineralogical characterization of commercial clays used in cosmetics and possible risk for health. Appl Clay Sci. 2016;119:449-54. http:// dx.doi.org/10.1016/j.clay.2015.10.023.

22. WHO: World Health Organization. Crystalline silica, quartz. Geneva: WHO; 2008. Concise International Chemical Assessment Document, no. 24

23. Favero JS, Parisotto-Peterle J, Weiss-Angeli V, Brandalise RN, Gomes LB, Bergmann CP, et al. Physical and chemical characterization and method for the decontamination of clays for application in cosmetics. Appl Clay Sci. 2016;124-125:252-9. http://dx.doi.org/10.1016/j.clay.2016.02.022.

24. Qtaitat MA, Al-Trawneh IN. Characterization of kaolinite of the Baten El- Ghoul region/south Jordan by infrared spectroscopy. Spectrochimica Acta Part A. 2005;61:1519-23. http://dx.doi. org/10.1016/j.saa.2004.11.008.

25. Dontosova KM, Norton LD, Johnston CT, Bigham JM. Influence of exchangeable cations on water adsoption on water by soil clays. Soil Sci Soc Am J. 2004;68:1218-27. http://dx.doi. org/10.2136/sssaj2004.1218.

26. Frost R, Mendelovici E. Modification of fibrous silicates surfaces with organic derivatives: an infrared spectroscopic study. J Colloid Interface Sci. 2006;294:47-52. http://dx.doi. org/10.1016/j.jcis.2005.07.014.

27. Madejová J. FTIR techniques in clay mineral studies. Vib Spectrosc. 2003;31:1-10. http://dx.doi.org/10.1016/S09242031(02)00065-6.

28. Makó E, Senkár Z, Kristóf J, Vágvölgyi V. Surfacemodification of mechanochemically activated kaolinites by selective leaching. J Colloid Interface Sci. 2006;294:362-70. http:// dx.doi.org/10.1016/j.jcis.2005.07.033.

29. Oinuma K, Hayashi H. Infrared study of mixed-layer clay minerals. Am Mineral. 1965;50:1213-27.

30. Worasith N, Goodman BA, Neampan J, Jeyachoke N, Thiravetyan P. Characterization of modified kaolin from the Ranong deposit Thailand by XRD, XRF, SEM, FTIR and EPR techniques. Clay Miner. 2011;46:539-59. http://dx.doi. org/10.1180/claymin.2011.046.4.539.

31. Ritz M, Zdrálková J, Valásková M. Vibrational spectroscopy of acid treated vermiculites. Vib Spectrosc. 2014;70:63-9. http:// dx.doi.org/10.1016/j.vibspec.2013.11.007.

32. Boulingui JE, Nkoumbou C, Njoya D, Thomas F, Yvon J. Characterization of clays from Mezafe and Mengono (NeLibreville, Gabon) for potential uses in fired products. Appl Clay Sci. 2015;115:132-44. http://dx.doi.org/10.1016/j. clay.2015.07.029.

33. Chmielarz L, Wojciechowska M, Rutkowska M, Adamski A, Węgrzyn A, Kowalczyk A, et al. Acid-activated vermiculites as catalysts of the DeNO(x) process. Catal Today. 2012;191:25-31. http://dx.doi.org/10.1016/j.cattod.2012.03.042.

34. Akyuz S, Akyuz T, Basaran S, Bolcal C, Gulec A. Analysis of ancient potteries using FT-IR, micro-Raman and EDXRF spectrometry. Vib Spectrosc. 2008;48(2):276-80. http://dx.doi. org/10.1016/j.vibspec.2008.02.011.

35. Poensin D, Carpentier P, Féchoz C, Gasparini S. Effects of mud pack treatment on skin microcirculation. Joint Bone Spine. 2003;70:367-70. http://dx.doi.org/10.1016/S1297319X(03)00064-2.

36. Brasil. Agência Nacional de Vigilância Sanitária - ANVISA. Resolução RDC n 481, de 23 de setembro de 1999. Estabelece os parâmetros de controle microbiológico para os produtos de higiene pessoal, cosméticos e perfumes. Diário Oficial da União; Brasília; 27 setembro 1999.

37. British Pharmacopeia. London: Her Majesty's Stationery Office; 2008.

38. Hong E, Kang D. Effect of sequential dry heat and hydrogen peroxide treatment on inactivation of Salmonella typhimurium on alfalfa seeds and seeds germination. Food Microbiol. 2016;53:9-14. http://dx.doi.org/10.1016/j.fm.2015.08.002.

39. Baranova I, Kovalenko SM, Khokhlenkova NV, Martyniuk TV, Kutsenko SA. Prospects of using synthetic and semi- synthetic gelling substances in development of medicinal and cosmetic gels. Asian Journal of Pharmaceutic. 2017;11:2-9. http://dx.doi. org/10.22377/ajp.v11i02.1267.

40. Fairclough JP, Norman J. Structure and rheology of aqueous gels. Annu Rep Prog Chem. 2003;99:243-76. 
41. Modabberi S, Namayandeh A, López-Galindo A, Viseras C, Setti M, Ranjbaran M. Characterization of Iranian bentonites to be used as pharmaceutical materials. Appl Clay Sci. 2015;116117:193-201. http://dx.doi.org/10.1016/j.clay.2015.03.013.

42. Weiss-Angeli V, Poletto FS, Zancan LR, Baldasso F, Pohlmann AR, Guterres SS. Nanocapsules of octyl methoxycinnamate containing quercetin delayed the photodegradation of both components under ultraviolet a radiation. J Biomed Nanotechnol. 2008;4(1):80-9. http://dx.doi.org/10.1166/jbn.2008.004.

43. Viseras C, Cultrone G, Cerezo P, Aguzzi P, Baschini MT, Valles $\mathrm{J}$, et al. Characterisation of northern Patagonian bentonite for pharmaceutical uses. Appl Clay Sci. 2006;31:272-81. http:// dx.doi.org/10.1016/j.clay.2005.11.002.

44. Buhse L, Kolinski R, Westenberger B, Wokovich A, Spencer J, Chenb CW, et al. Topical drug classification. Int J Pharm. 2005;295:101-12. http://dx.doi.org/10.1016/j.ijpharm.2005.01.032.
45. Estanqueiro M, Amaral MH, Lobo SJM. Comparison between sensory and instrumental characterization of topical formulations: impact of thickening agents. Int J Cosmet Sci. 2016;38:389-98. http://dx.doi.org/10.1111/ics.12302.

46. Bastos-Leal L, Sousa GD, Seixas CB, Souza PHN, Davi Pereira de Santana DP. Determination of the critical hydrophile-lipophile balance of licuri oil from Syagrus coronata: application for topical emulsions and evaluation of its hydrating function. Brazilian of Pharmaceutical Sciences. 2013;49:167-73. http:/ dx.doi.org/10.1590/S1984-82502013000100018.

47. Silva PSC, Oliveira SMB, Farias L, Fávaro DIT, Mazzilli BP. Chemical and radiological characterization of clay minerals used in pharmaceutics and cosmetics. Appl Clay Sci. 2011;52:145-9. http://dx.doi.org/10.1016/j.clay.2011.02.013. 